\title{
17. IRON-RICH SEDIMENTS CORED DURING LEG 8 OF THE DEEP SEA DRILLING PROJECT
}

\author{
C. C. von der Borch, W. D. Nesteroff, and J. S. Galehouse
}

\begin{abstract}
A sequence of amorphous iron oxide-rich sediments, interbedded with iron-free calcareous nannoplankton oozes, occurs in the basal zones of Sites 74 and 75 of the Deep Sea Drilling Project, immediately overlying basalt. These sediments have affinities with iron and manganeserich sediments previously described from the crest of the East Pacific Rise. It is considered most likely that this sediment association forms a basal iron and manganeserich facies over much of the central east Pacific Basin and that it was formed by precipitation from bottom waters which were enriched in metals by submarine hydrothermal exhalations associated with volcanism.
\end{abstract}

\section{INTRODUCTION}

Two of the sites of Leg 8 of the Deep Sea Drilling Project, 74 and 75 (Figure 1), reached basaltic rock. Both

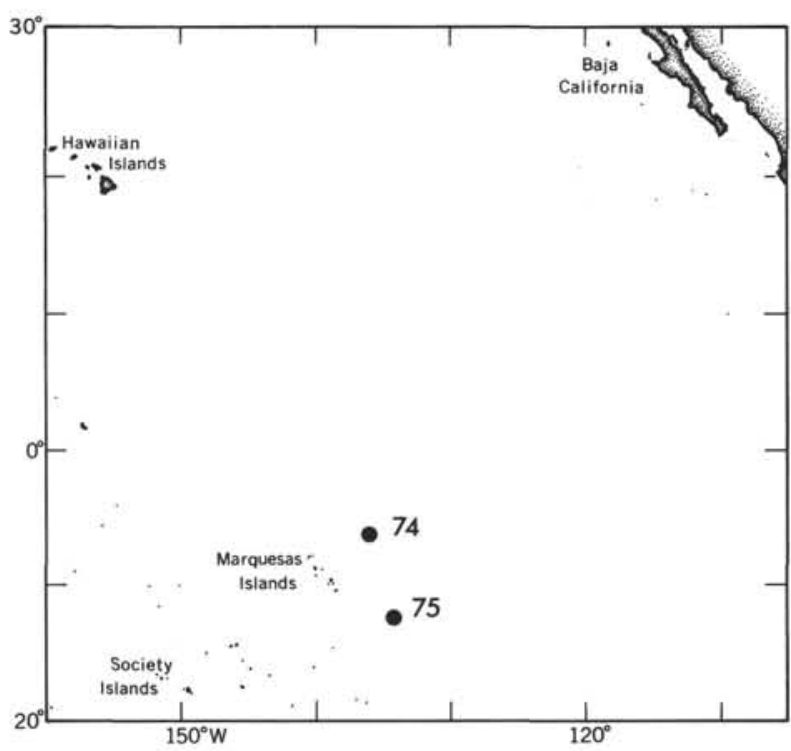

Figure 1. Locality chart of Sites 74 and 75, Leg 8, Deep Sea Drilling Project. The 2000 fathom isobath is shown. sites are situated south of the equatorial zone of high productivity and consequently are within an area of relatively thin sediment cover over the basal seismic reflector. The sediment column at both sites is almost entirely a light-colored biogenic ooze. However, basal sediments overlying basaltic rock are composed of dark yellowish-brown beds sharply interbedded with contrasting pale yellow calcareous ooze (Figure 2). In addition, some zones higher in the sediment column at Site 74 show the existence of similar dark-colored material in the form of a discrete bed and as pigmentation in radiolarian ooze.

Smear slide observations show the dark-colored material to be composed of a fine-grained, granular, optically isotropic iron mineral, admixed in varying proportions with biogenic components. The biogenic material is dominantly calcareous nannoplankton. This association is identical to that of basal sediments from east Pacific drill Sites 37, 38, and 39 of Leg 5 documented by von der Borch and Rex (1970). The material is also similar to iron and mangąnese oxide-rich sediments described by Bostrom and Peterson (1966), Bostrom and Peterson (1969), and Bostrom, Peterson, Joensuu and Fisher (1969) from crestal areas of active mid-ocean ridges, particularly the East Pacific Rise. Broadly similar deepsea iron oxide minerals, in this case deficient in manganese, have been described by Bonatti and Joensuu (1966) from flanks of a seamount on the East Pacific. 


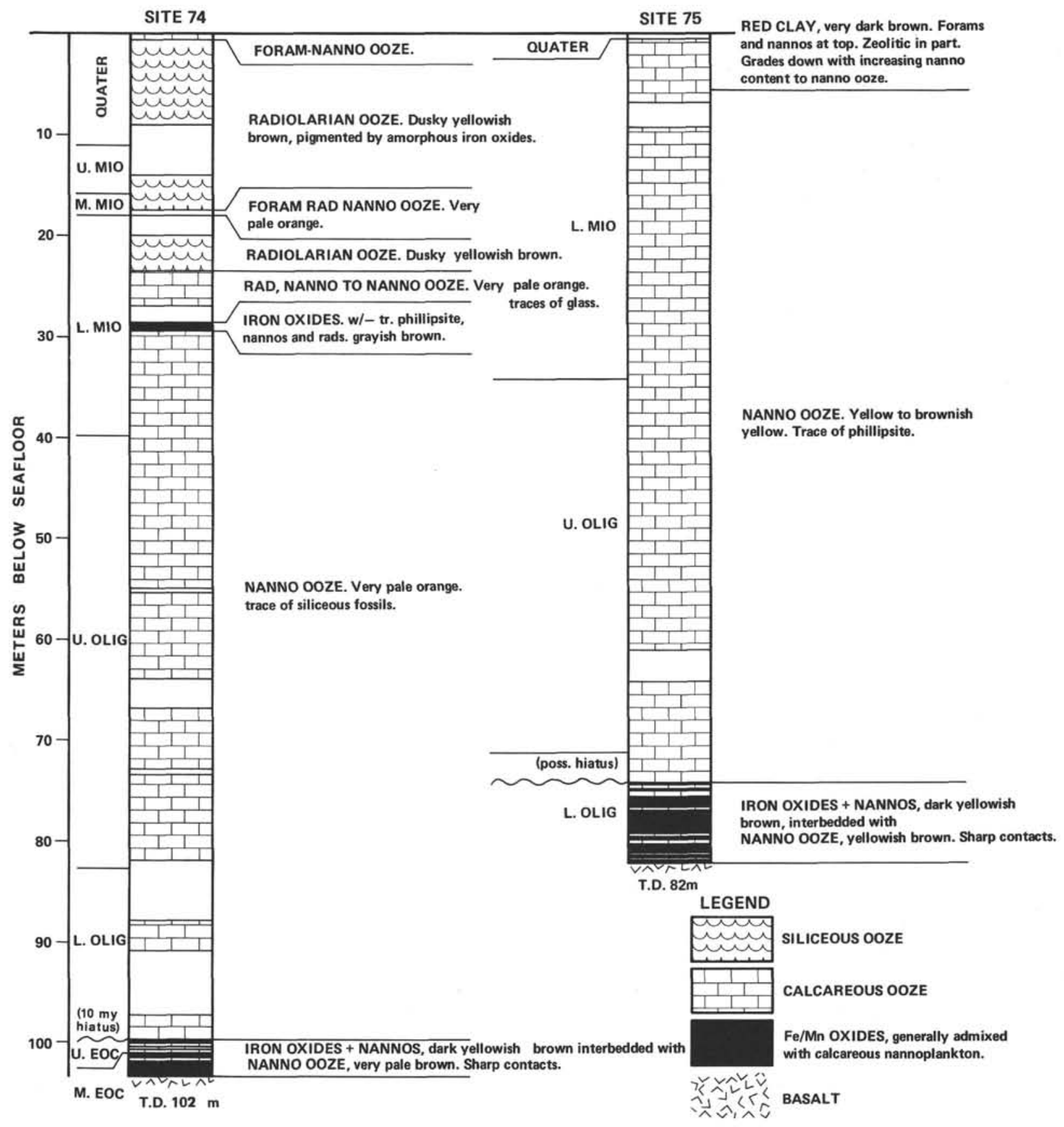

Figure 2. Stratigraphic columns of Sites 74 and 75 of the Deep Sea Drilling Project. Color code is from the U.S. G. S. rock color chart. 
Rise. Finally, the Leg 8 sediments resemble, at least superficially, the amorphous goethite facies of the Red Sea metalliferous muds (Bischoff, 1969). Such an ironmanganese oxide association appears, therefore, to be of quite widespread occurrence in oceanic sediments, at least in basal sediments of the East Central Pacific Basin. This paper summarizes the mineralogy and stratigraphy of these sediments in Sites 74 and 75 of Leg 8 of the Deep Sea Drilling Project.

\section{DEFINITION}

At this time, chemical analyses of the ferruginous sediments cored during Leg 8 are not available. Because of this, the metalliferous components of the sediments will be referred to in this paper as amorphous iron oxides or iron oxides, despite the fact that they may contain appreciable manganese, as did the Leg 5 samples. Comparable material from the crest of the East Pacific Rise (Bostrom and Peterson, 1969) is rich in manganese and enriched in trace metals such as boron, arsenic, chromium, cadmium, lead, vanadium, mercury and barium.

The word amorphous refers to the fact that the oxides are essentially non-diffracting with respect to X-rays, and appear amorphous under the polarizing microscope.

\section{MINERALOGY AND STRUCTURE}

The mineral occurs in the form of discrete yellow-brown translucent spherules and aggregates which range in diameter from 0.5 to 25 microns. Associated with these aggregates are appreciable amounts of colloidal matter which, on dispersal in distilled water, produce a stable reddish-brown suspension.

Scanning electron micrographs of the spherules (Plate 1) show them to be roughly spherical in shape. Surface textures are variable but commonly consist of a felted texture of rod-like forms, about 0.1 micron in section and 1 micron in length, reminiscent of sheaths of irondepositing bacteria (Plate 1, Figure 1). Other surface textures have a more crystalline appearance (Plate 1, Figures 2 and 3). It is uncertain at this stage whether the rod-like structures are due to microorganisms. It is considered equally probable that they could be an inorganic phenomenon, perhaps analogous to tubular crystals of $\beta$-iron (III) oxide hydroxide, described by Gallagher (1970).

\section{STRATIGRAPHY, SITE 74 (SEE FIGURE 2)}

Uppermost 23 meters of sediment at Site 74 comprises the Clipperton Formation, consisting of dusky yellowish-brown radiolarian ooze of lower Miocene to Quaternary age overlain by a few centimeters of Quaternary foraminiferal-nannofossil ooze at the present sea floor. The dark-colored radiolarian ooze is pigmented by a few per cent of iron oxides, in the usual form of microscopic, translucent, yellowish-brown spherules and aggregates.

Below the Clipperton Formation, at a sediment depth of 23 meters, the dominantly siliceous sediments are replaced by a pale yellowish-brown calcareous nannoplankton ooze of the Marquesas Formation, containing fragmentary siliceous fossils and traces of volcanic glass. This is underlain in the lower Miocene, at a depth of 28.5 meters, by a 40-centimeter thick bed of very dark grayish-brown sediment containing iron oxides. These are mixed in some zones with siliceous and calcareous microfossils and in others with phillipsite laths and calcareous nannoplankton. The oxides are present, as before, in the form of microscopic, translucent, subspherical grains and aggregates and as distinct in-fillings within foraminiferal tests and diatom frustules. Some frustules have been completely filled with dark-colored oxides, resulting in almost opaque discs.

Below a sediment depth of 29 meters the sediment at Site 74 is dominated by light-colored calcareous nannoplankton ooze, with no ferruginous admixture, down to the base of the lower Oligocene.

A hiatus is present between the lower Oligocene nannoplankton oozes of the Marquesas Formation and underlying upper and middle Eocene sediments of the Line Islands Formation. A distinct lithologic break is evident at this hiatus, in which nannoplankton ooze is sharply underlain by a basal unit, 3.7 meters thick, composed of five dark yellowish-brown zones of iron oxide and mannoplankton, interbedded with contrasting very pale brown to white nannoplankton oozes. The dark-colored zones are between 5 and 160 centimeters in thickness and contain up to an estimated 50 per cent iron oxide, associated with calcareous nannoplankton. These are separated by sharp contacts from the interbedded lightcolored calcareous zones, which are nearly free from iron oxides. The oxide-free zones vary from 5 to 40 centimeters in thickness in the cores. Occasionally, very dark brown layers, several centimeters in thickness, are present within the dark brown iron oxide-rich sediments, particularly at some of the contacts with pure calcareous oozes.

A fragment of manganese oxide-encrusted basalt was cored from the bottom of this hole at a depth of 103.5 meters, associated with a fragment of indurated limestone possibly containing some ash. A gingercolored ash, composed of devitrified shards, is present within the lowermost zone of the basal iron oxide layer.

\section{STRATIGRAPHY, SITE 75 (SEE FIGURE 2)}

The surface sediment of Site 75 is a thin, very dark brown zeolitic clay, containing calcareous nannoplankton and foraminifera of mixed Miocene to 
Quaternary age at the sea-floor. This grades down at a depth of about 3 meters to a thick, calcareous nannoplankton ooze unit which extends down through the lower Miocene to lower Oligocene. At this level, at a sediment depth of 71 meters, the light yellowish-brown hue becomes slightly darker and small quantities of the iron oxides are visible in smear slides. At a depth of 74 meters there is a very sharp boundary between the overlying nannoplankton ooze and an underlying interbedded iron oxide plus nannoplankton ooze and pure nannoplankton ooze unit, similar to Site 74. Thickness of the basal unit at this site is 8.1 meters. A series of eight interbeds of dark colored, iron-rich nannoplankton ooze zones with sharp contacts are present in this basal section from 74 meters down to the basalt contact. The ferruginous beds, which contain an estimated 40 to 50 per cent oxides, vary from 30 to 240 centimeters in thickness. The interbedded light-colored nannoplankton oozes vary from 10 to 30 centimeters in thickness. As at Site 74, occasional darker bands several centimeters in thickness are present within the iron oxide beds; in one instance they form the upper zone of a sharp contact between an underlying iron oxide-rich layer and an overlying nannoplankton ooze. Basal sediments of Site 75 are younger than the equivalent beds of Site 74 , being of lower Oligocene age. A possible hiatus or zone of slow deposition separates the iron-rich sediments from overlying, essentially iron oxide-free calcareous oozes. This hiatus occurs in the P.21 (Globorotalia opima opima) Zone (Berggren, 1969) of the Tertiary. See Part III: Biostratigraphy (this volume).

\section{DISCUSSION}

As far as the iron oxide sediments are concerned, the most notable observation of DSDP Sites 74 and 75 is the fact that distinct beds of iron-free calcareous pelagic ooze occur within the basal iron oxide facies, interbedded with iron-oxide rich layers. This contrasts with Sites 37,38 and 39 of Leg 5 in which the basal sediments invariably contain iron oxides with no iron-free interbeds. The interbedded iron-free pelagic layers in basal sediments of Sites 74 and 75 bear out the supposition that the ferruginous material is syngenetic with the sediment and thus has not been introduced by permeation from below. The data best fit a model in which definite episodes of precipitation of metal oxides from bottom waters occur in a given area, separated by periods of normal calcareous pelagic sedimentation. Alternatively, continuous exhalation could possibly exist with variations in the bottom current pattern causing the episodic precipitation of metal oxides. In either case it is considered that volcanic hydrothermal exhalations are responsible for periodically enriching bottom waters in the necessary elements, as suggested in Bostrom and Peterson (1966) for the surficial sediments of the East Pacific Rise.

In all of the Deep Sea Drilling sites that to date have encountered these iron oxide sediments, it is apparent that they are present most strongly as a basal facies in the few meters or tens of meters immediately overlying basalt. This supports the reasoning that they are related in some manner to sea floor volcanism or at least to the presence of basalt. The oxides are either sparesely distributed or entirely absent higher in the sediment column, except for the distinct horizon in Site 74.

The observation by Bostrom and Peterson $(1966,1969)$ that the oxides are strongly concentrated in surface sediments along the zones of high heatflow on the crest of the East Pacific Rise has been interpreted by those authors to indicate a source of hydrothermal exhalations coinciding with those zones. They suggest that subsequent spreading of the ocean floor away from the risecrest, accompanied by dilution with pelagic material, would result in a basal zone enriched in the iron oxides which would grade upward in the sediment column into normal pelagic sediments.

This model readily explains the stratigraphy of the iron oxide sediments at Sites 37, 38 and 39 (von der Borch and Rex, 1970). However, no such upward gradation is present at Sites 74 and 75 . In both cases, the basal interbedded facies terminates abruptly in an upward direction and is replaced by mainly iron-free pelagic calcareous ooze. The abrupt change is readily explainable in Site 74, in which case a 100 million year hiatus exists approximately at the top of the iron oxide unit. In Site 75 the break in lithology may also coincide with a hiatus, although it is not as obvious as in the previous example. Using the model of Bostrom and Peterson (1969), in which hydrothermal exhalations are located along the rise crests, it is possible to explain the lack of upward gradation in the proportion of iron oxides in sediments of Sites 74 and 75 by the presence of the hiatuses. The time represented by the breaks in the sedimentary record would allow the areas in question to move out of the range of iron-enriched bottom waters by the process of sea-floor spreading.

Another feasible source of iron and manganese from volcanic exhalations could be the Marquesas volcanic pedestal. The chart (Figure 1) shows the proximity of Sites 74 and 75 to this area, which may have been active during early Tertiary times.

A completely different mode of origin for the iron-rich sediments would be one of scavenging of the iron and other elements from solution by microorganisms. Irondepositing bacteria can exist under aerobic conditions on the sea floor and their vital activities could be enhanced in the vicinity of basaltic rock, perhaps during submarine weathering or deuteric alteration of the lava flows. This could presumably cause concentrations of bacterially-precipitated iron oxides immediately above basalt and may explain the possible bacterial structures shown in Plate 1, Figure 3. 
Whatever their mode of origin, the direct association of basaltic rocks with iron and manganese oxide-rich sediments is reminiscent of some of the Archaean banded iron formations that occur on continental shield areas. The iron-manganese sediments of Leg 5, for example (von der Borch and Rex, 1970), contain up to 27.8 per cent iron, an as yet undetermined amount of manganese, and abundant amorphous material that may be in part silica. It is possible that a banding of iron oxide-rich layers and silica-rich layers could be produced either diagenetically or by subsequent metamorphism of these deposits to produce a banded iron formation which would resemble some of the ancient deposits both in mineralogy and lithologic association.

\section{ACKNOWLEDGEMENTS}

Scanning electron micrographs were taken by S. Margolis of the Department of Biogeology, University of California at Santa Barbara. Dr. J. Tracey, Jr., kindly reviewed the manuscript.

\section{REFERENCES}

Berggren, W. A., 1969. Cenozoic chronostratigraphy, planktonic foraminiferal zonation and the radiometric time scale. Nature. 224, 1072.
Bischoff, J. L., 1969. Red Sea geothermal brine deposits: Their mineralogy, chemistry and genesis. In Hot brines and Recent Heavy Metal Deposits in the Red Sea. Degens and Ross (Eds). New Yrok (SpringerVerlag) 368.

Bonatti, E. and Joensuu, O., 1966. Deep-sea iron deposit from the South Pacific. Science. 154, 643.

Bostrom, K. and Peterson, M. N. A., 1966. Precipitates from hydrothermal exhalations on the East Pacific Rise. Econ. Geol. 61, 1258.

Bostrom, K. and Peterson, M. N. A., 1969. The origin of aluminum-poor ferromanganoan sediments in areas of high heat flow on the East Pacific Rise. Marine Geol. 7, 427.

Bostrom, K., Peterson, M. N. A., Joensuu, O. and Fisher, D. E., 1969. Aluminum-poor ferromanganoan sediments on active oceanic ridges. J. Geophys. Res. 74, 3261 .

Gallagher, K. J., 1970. The atomic structure of tubular subcrystals of $\beta$-iron (III) oxide hydroxide. Nature. 226, 1225.

von der Borch, C. C. and Rex, R. W., 1970, Amorphous iron oxide precipitates in sediments cored during Leg 5, Deep Sea Drilling Project. In McManus et al., 1970, Initial Reports of the Deep Sea Drilling Project, Volume V. Washington (U.S. Govt. Printing Office), 541. 


\section{PLATE 1}

Scanning electron micrographs of typical spherules of amorphous iron oxides, Site 74.

Figure $1 \quad$ Spherules composed of a felted mass of rod-shaped structures.

Figure 2 Spherule showing an apparently crystalline surface texture.

Figure 3 Spherule showing what appears to be a crystalline surface texture. Note presence of coccoliths. 
PLATE 1

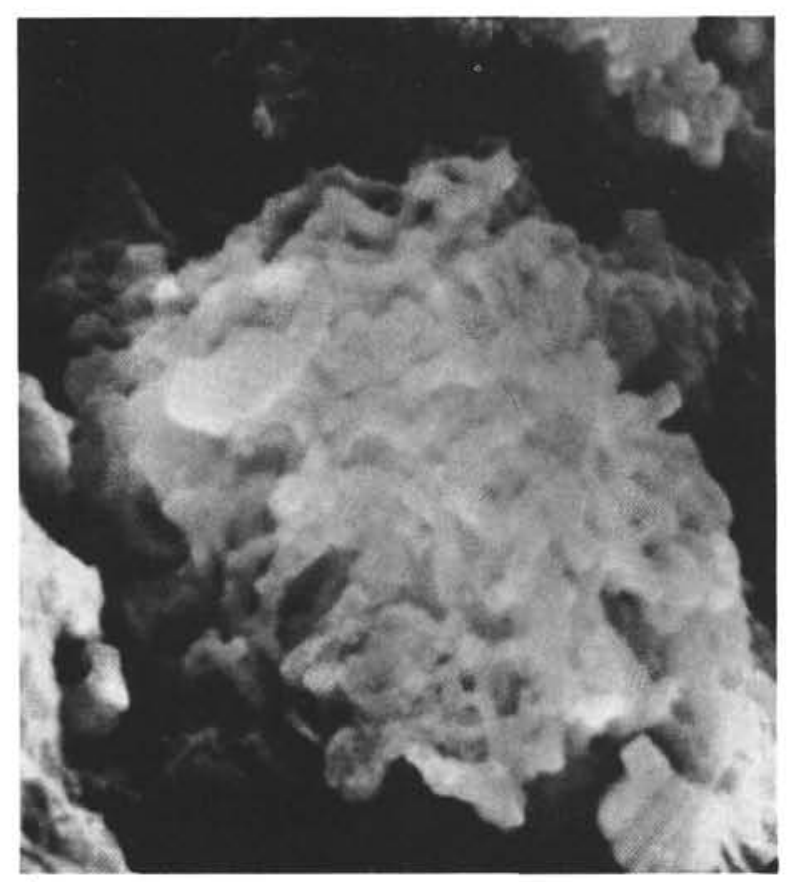

1

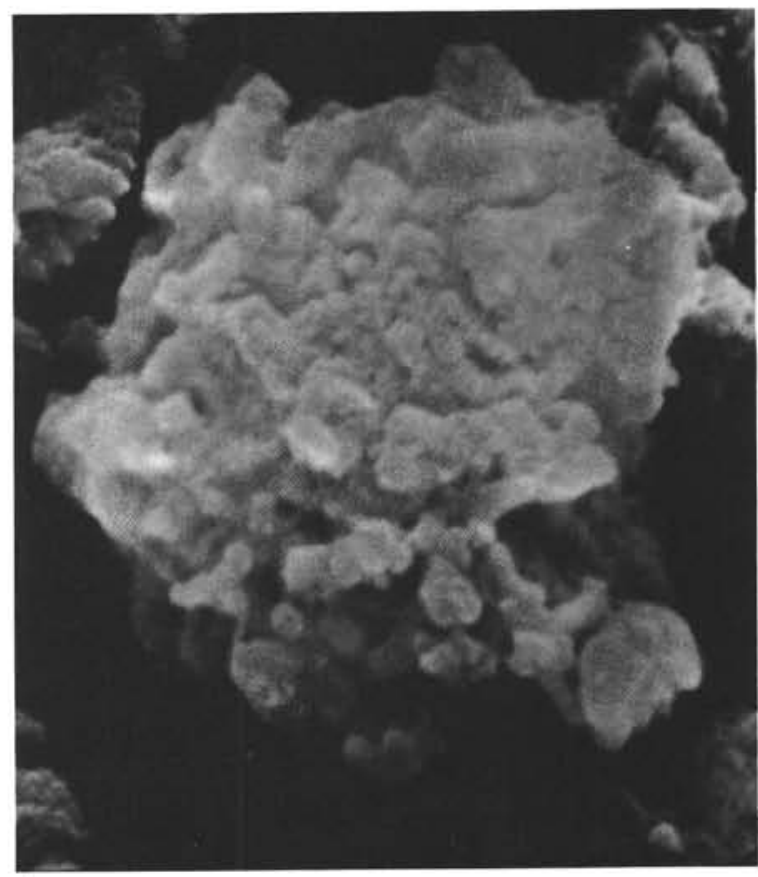

2

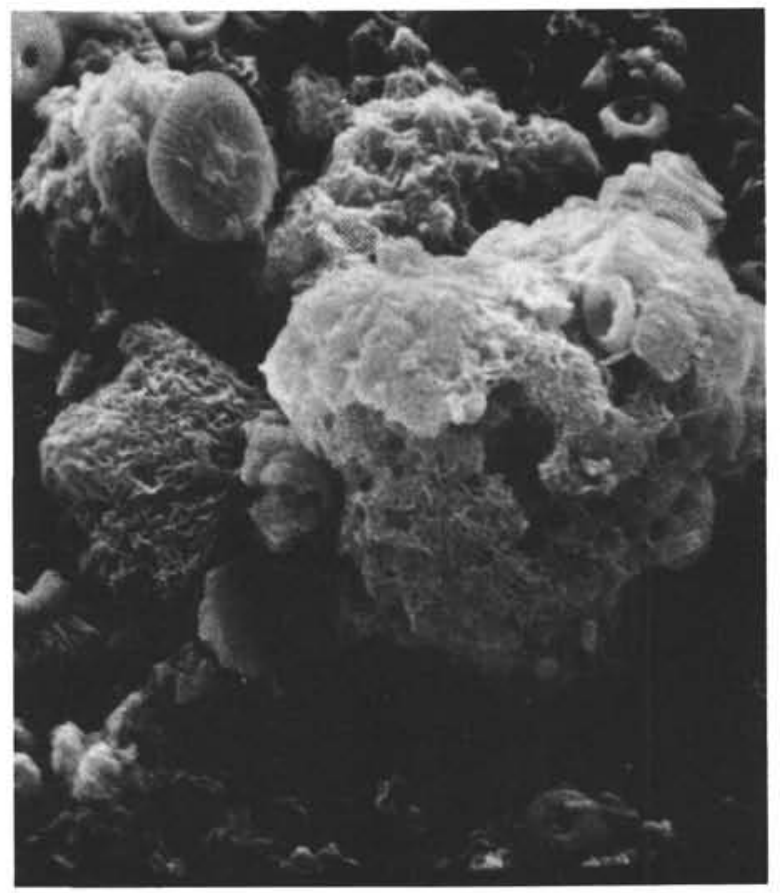

3

- SCALE - MICRONS

10 